UDC 598.231

I. V. Dykyy ${ }^{1,2}$, G. P. Milinevsky ${ }^{2,3,4, *}$, O. L. Savitsky ${ }^{5}$, D. G. Lutsenko ${ }^{6}$, P. B. Khoetsky ${ }^{2,}{ }^{7}$, M. F. Veselsky ${ }^{8}$, V. M. Smagol ${ }^{9}$, Ye. O. Dykyy ${ }^{2}$, A. O. Dzhulay ${ }^{2}$, J. V. Tsaryk ${ }^{1}$, K. M. Nazaruk ${ }^{1}$, A. T. Zatushevsky ${ }^{10}$, A. O. Simon ${ }^{4}$, M. A. Telipska ${ }^{1}$

${ }^{1}$ Ivan Franko National University of Lviv, 1 Universytetska Str. , Lviv, 79005, Ukraine

${ }^{2}$ State Institution National Antarctic Scientific Center, Ministry of Education and Science of Ukraine, 16 Taras Shevchenko Blvd., Kyiv, 01601, Ukraine

${ }^{3}$ College of Physics, International Center of Future Science, Jilin University,

2699 Qianjin Str., Changchun, 130012, China

${ }^{4}$ Taras Shevchenko National University of Kyiv, 64/13 Volodymyrska Str., Kyiv, 01601, Ukraine

${ }^{5}$ Institute of Hydrobiology, National Academy of Sciences of Ukraine, 12 Geroiv Stalingradu Ave, Kyiv, 04210, Ukraine

${ }^{6}$ Institute for Problems of Cryobiology and Cryomedicine, National Academy of Sciences of Ukraine,

23 Pereiaslavska Str., Kharkiv, 61016, Ukraine

${ }^{7}$ National Forestry University of Ukraine, 103 General Chuprynka Str., Lviv, 79057, Ukraine

${ }^{8}$ Zhytomyr Regional Museum of Local Lore, 1 Zamkovyi Maidan, Zhytomyr, 10014, Ukraine

${ }^{9}$ I. I. Schmalhausen Institute of Zoology, National Academy of Sciences of Ukraine,

15 Bohdan Khmelnytskyi Str., Kyiv, 01030, Ukraine

${ }^{10}$ Zoological Museum of Ivan Franko National University of Lviv, 4 Mykhaila Hrushevskoho Str. , Lviv, 79005, Ukraine

*Corresponding author: genmilinevsky@jlu.edu.cn, genmilinevsky@gmail.com

\title{
FEATURES OF CHRONOLOGY AND BREEDING SUCCESS OF PYGOSCELIS PAPUA AND P. ADELIAE (SPHENISCIDAE) PENGUINS IN THE WILHELM ARCHIPELAGO (CCAMLR SUBAREA 48.1)
}

\begin{abstract}
Objective. To investigate the qualitative changes in the habitats of two most common species penguin populations in the Wilhelm Archipelago Pygoscelis papua and P. adeliae (Spheniscidae) penguins in the CCAMLR Subarea 48.1 under the impact of climate changes and krill fishery. Methods. The new method of time-lapse camera registration to observe the breeding success of penguins was applied to minimize the effect of human disturbance on the breeding and survival of chicks and to avoid disturbance of penguins. Installed in penguin colonies cameras were used to record next parameters: arrival to colony, copulation, egg lay, hatch and crèche. This method was introduced for the first time in the framework of the international CEMP project "Establishing a CEMP Camera Network in Subarea 48.1". More than five years' timeline of the project is expected. The traditional visual observation of penguin colonies from time to time has been used as well. Results. Over the last decade, P. papua has been shifted nearly $30 \mathrm{~km}$ southward and formed six new nesting colonies. Annual breeding success of $P$. papua on Petermann Island has ranged from 0.87 to 1.58 chicks crèche per nest over the nine seasonal observations during 2003-2017. 1.27 chicks per nest was found in 2016/17 season; a low breeding success rate in comparison to most of other seasons. The breeding success of $P$. adeliae was more stable ranging from 1.11 to 1.42 over the six seasonal observations; with highest in 2003/04. The range of prey for $P$. papua was studied. Conclusions. Changes in the penguin species habitat have been observed on the territory of the Wilhelm Archipelago. It was established that at the beginning of the XXI century the nesting areas of P. papua was significantly extended probably due to the climate warming in the region. It was shown that $P$. papua is more ecologically plastic species than $P$. adeliae. It is well know that the breeding success of predators such as penguins can be used as an indication of the status of lower trophic levels. Since, the Antarctic krill Euphausia superba (Euphausiidae) is the main feeding object of the both penguin species diet (84\%) in the Wilhelm Archipelago area, we propose a model of key elements for qualitative and quantitative analysis of the changes in the krill- based ecosystem of the Argentine Islands. Future development of the penguin nesting colonies monitoring using the CEMP Camera Network under the CCAMLR will contribute significantly to the real-time estimates of relative prey availability. The results of the gentoo and Adelie penguin's chronology and breeding success studies might be used (1) in development of the krill fishery management strategy in the CCAMLR for the rational use of Antarctic marine living resources; (2) to develop a resettlement model to predict the ecological risks due to climate changes for both penguin species.
\end{abstract}

Keywords: Pigoscelis papua, Pigoscelis adeliae, breeding success, stomach content, krill, CEMP Camera Network, Antarctic Peninsula.

(C) I. V. DYKYY, G. P. MILINEVSKY, O. L. SAVITSKY, D. G LUTSENKO, P. B. KHOETSKY, M. F. VESELSKY, V. M. SMAGOL, Ye. O. DYKYY, A. O. DZHULAY, J. V. TSARYK, K. M. NAZARUK, A. T. ZATUSHEVSKY,

A. O. SIMON, M. A. TELIPSKA, 2018 


\section{INTRODUCTION}

The first registrations and records of Pygoscelis papua (gentoo) and Pygoscelis adeliae (Adelie) penguins were carried out in the territory of the Wilhelm Archipelago in 1904 during the French and Swedish expeditions led by J.-B. Charcot and O. Nordenskjöld (Gain, 1914). The detailed surveys of both penguin species in breeding colonies of the Booth, Petermann, Yalour and Argentine Islands during the 1950s and 1980s were carried out by the British Antarctic Survey (BAS) (Muller-Schwarze and Muller-Schwarze, 1975; Croxall, Kirkwod, 1979; Poncet and Poncet, 1987). The first Ukrainian ornithological studies at Wilhelm Archipelago territories were started in 1998-99 during the $3^{\text {rd }}$ Ukrainian Antarctic Expedition (UAE) by A.M. Peklo, who thoroughly studied an ornithofauna of the Argentine Islands and Petermann Island nearby. Further studies were continued by S.A. Lopariev in 2000/01 ( $5^{\text {th }}$ UAE), M.I. Golovushkin in 2001/02 $\left(6^{\text {th }}\right.$ UAE), D.V. Pilipenko in $2010 / 11,2013 / 14\left(15^{\text {th }}\right.$ and $18^{\text {th }}$ UAE), M.F. Veselsky in $2013 / 14,2015 / 16$ $\left(18^{\text {th }}\right.$ and $\left.20^{\text {th }} \mathrm{UAE}\right)$. Over all 22 years of the scientific work at the Ukrainian Antarctic Akademik Vernadsky station biologists carried out monitoring of the ornithofauna, including the P. papua and P. adeliae penguins (Peklo, 2001, 2007; Loparev, 2003; Peklo and Dykyy, 2010; Pylypenko, 2013; Chesalin, 2007/ 08; Chesalin et al., 2009; Dykyy, 2013; Dykyy et al., Smagol and Molchanov, 2016). In the summer seasons 2003-2008 the monitoring of the nesting colonies of $P$. papua and $P$. adeliae in Petermann Island was carried out by the team of American ornithologists headed by R. Naveen (Lynch et al., 2010). However, most of the previous studies have provided faunistic data, distribution, numbers, ringing of chicks and some other aspects of the certain species ethology only.

The 45 remote automated cameras joined in network along Antarctic Peninsula were used for monitoring of the reproduction chronology and breeding status of penguin populations for the first time in Subarea 48.1. The effectiveness of the camera use has already been demonstrated in East Antarctica (Southwell, Emmerson and Newbery 2011; Southwell et al.,
2013). Analysis of the penguins' habitats in the CCAMLR Subarea 48.1 is important for assessment of the status of populations and habitats of the major krill consumers in Antarctica and identification of the potential overlapping of their habitats with important areas of krill commercial fishing. The biologists of the UAE carry out constant monitoring and accumulate continuous records of the penguins' nesting behavior over two seasons and wintering without personal presence all-year-round despite extreme weather conditions using the automatic cameras' network.

There are many processes that impact on forming the biota of the region along with natural factors. Unfortunately, anthropogenic impact cannot be prevented even in Antarctica. Actually it is essentially important to observe and search for the relationship between biota's state and degree of anthropogenic load. Modern approaches require the consideration of any ecosystem as an environment of the organisms' existence (Afanasyev, 2006). The concept on the priority of biotic criteria in establishment of the "ecological state" over all others, namely hydrochemical, hydrological, climate, etc., is directly pointed in the important international document - Marine Strategy Framework Directive EU (Olenin, 2010), which was ratified by Ukraine.

The aim of this work was to investigate qualitative changes in the habitats of P. papua and P. adeliae penguin populations in the CCAMLR Subarea 48.1 under the influence of climate change and krill fishery, particularly nesting behavior, feeding and breeding of penguins as key species of the Antarctic ecosystem. The obtained results will be used in the program of monitoring and forecasting of the krill population size (CCAMLR Ecosystem Monitoring Program CEMP) of the Commission on Conservation Marine Living Resources (CCAMLR). This work is aimed in supporting and development of research of penguin breeding colonies - the key indicator of the krill population size - using the network of automatic cameras CEMP installed by Ukrainian scientists in the Wilhelm Archipelago (Great Yalour Island, Galindez Island and Petermann Island, Western Antarctica) within the framework of the international CEMP project "Establishing a CEMP Camera Network in Subarea 48.1". 


\section{METHODS}

The breeding colonies of P. papua and P. adeliae penguins are the objects of the study. The subject of the research is the chronology of reproduction and breeding success of their populations.

Standard methods, as prescribed by CCAMLR, were used. These are referred to in the text as CEMP A1 to A9 (CCAMLR, 1997). The nine remote automatic cameras Reconix PC800 Hyperfire Professional IR type were used. Cameras have been provided within the framework of the international CEMP (CAMLR Ecosystem Monitoring Program) project "Establishing a CEMP Camera Network in Subarea 48.1". Particularly, participants of the $20^{\text {th }}$ UAE have installed six tripods on Galindez, Petermann and Yalour Islands, and set up nine cameras after the breeding season started: on 01.01.2016 at the colonies on Galindez Island ( 3 cameras), 01.15.2016 on the Petermann Island (3 cameras), 01.20.2016 on Great Yalour Island ( 3 cameras) to control nine areas in the P. papua and P. adeliae colonies for the first time (Hinke et al, 2018). The coordinates of the installation points are shown in Table 1.

After 2015/2016 season the cameras' names and their location were corrected: Galindez Island (GBV), Penguin Point (GPP) - camera GBV and cameras GPP1 and GPP2; Yalour Island (YAL site) - cameras YAL1, YAL2 and YAL3; and Petermann Island (PTI site) - cameras PTI1, PTI2 and PTI3. Annual average number of photos for tracking behavior and reproduction success was about 3.5 thousand per one colony. Each camera produces daily 10 shots with interval of 30 minutes from 10:00 a.m. until 2:30 p.m. LT (Local Time). The camera at each photo provides information on air temperature, time and date of shooting. When weather permits the visual records of eggs and chicks' appearance and numbers by provided with biologists in breeding colonies in Petermann, Yalour and Galindez Islands to control the results of photo registration. As a result, over 2016/ 2017 summer season in $21 \mathrm{UAE}$ the number of the obtained photos is: at Galindez Island - 9970, at Petermann Island 10860 and at Yalour Island - 11310. The information of 34849 photos was processed over two years.

The chronology of the birds' breeding was analyzed using the set of $8-10$ daily photos, and the reproductive success of the population was measured by comparative analysis of observations at the beginning and at the end of the breeding season. The results of images analysis were verified by standard statistical methods. The general observational data were included into standard CEMP protocols and submitted to the CCAMLR Secretariat.

The main events/numbers that have to be registered are: the appearance of the first penguins in the colony; copulation date; laying of the first egg, second, third; hatching of the first chicks, the second, third; the date when the chicks leave the nest and crowded in the crèche have also to be registered. The number of eggs, chicks and number of chicks survived to the end of the season from each nest. Accor-

Table 1. Automatic camera sites coordinates

\begin{tabular}{|l|c|c|c|l|}
\hline Code of section & Installation date & Coordinates & Altitude a. s. 1. & \multicolumn{1}{c|}{ Location } \\
\hline PTI1 & 15-JAN-16 & $\mathrm{S}^{\circ} 65^{\circ} 10^{\prime} .606, \mathrm{~W} 64^{\circ} 08^{\prime} .277$ & $20 \mathrm{~m}$ & Petermann Island \\
PTI2 & 15-JAN-16 & $\mathrm{S}^{\circ} 5^{\circ} 10^{\prime} .586, \mathrm{~W} 64^{\circ} 08^{\prime} .347$ & $32 \mathrm{~m}$ & Petermann Island \\
PTI3 & 15-JAN-16 & $\mathrm{S}^{\circ} 5^{\circ} 10^{\prime} .586, \mathrm{~W} 64^{\circ} 08^{\prime} .347$ & $32 \mathrm{~m}$ & Petermann Island \\
YAL1 & 20-JAN-16 & $\mathrm{S}^{\circ} 5^{\circ} 14^{\prime} .124, \mathrm{~W} 64^{\circ} 09^{\prime} .843$ & $20 \mathrm{~m}$ & Great Yalour Island \\
YAL2 & 20-JAN-16 & $\mathrm{S}^{\circ} 5^{\circ} 14^{\prime} .103, \mathrm{~W} 64^{\circ} 09^{\prime} .871$ & $24 \mathrm{~m}$ & Great Yalour Island \\
YAL3 & 20-JAN-16 & $\mathrm{S}^{\circ} 5^{\circ} 14^{\prime} .103, \mathrm{~W} 64^{\circ} 09^{\prime} .871$ & $24 \mathrm{~m}$ & Great Yalour Island \\
GPP1 & 01-JAN-16 & $\mathrm{S}^{\circ} 5^{\circ} 14^{\prime} .885, \mathrm{~W} 64^{\circ} 14^{\prime} .353$ & $6 \mathrm{~m}$ & Galindez Island, Penguin Point \\
GPP2 & 01-JAN-16 & $\mathrm{S}^{\circ} 5^{\circ} 14^{\prime} .885, \mathrm{~W} 64^{\circ} 14^{\prime} .353$ & $6 \mathrm{~m}$ & Galindez Island, Penguin Point \\
GBV & 01-JAN-16 & $\mathrm{S}^{\circ} 5^{\circ} 14^{\prime} .41, \mathrm{~W} 64^{\circ} 15^{\prime} .21$ & $4 \mathrm{~m}$ & Galindez Island, Marina Point \\
\hline
\end{tabular}


ding to this algorithm, images were processed from all nine cameras. From 8 to 18 nests were observed by each camera. To develop data that characterize the colony it was necessary to select photos covering as many nests as possible and numerate them. Further activities included monitoring of the nests and behavioral changes in the specially designed protocols of two different forms for the chicks and adult specimens. The "adult" form requires registration of parental visits to the nest, and the "chick" form requires registration of the moments from copulation date until the chicks leave the nest.

Work on elaboration of the key elements for the model of a qualitative changes in the krill-based eco-

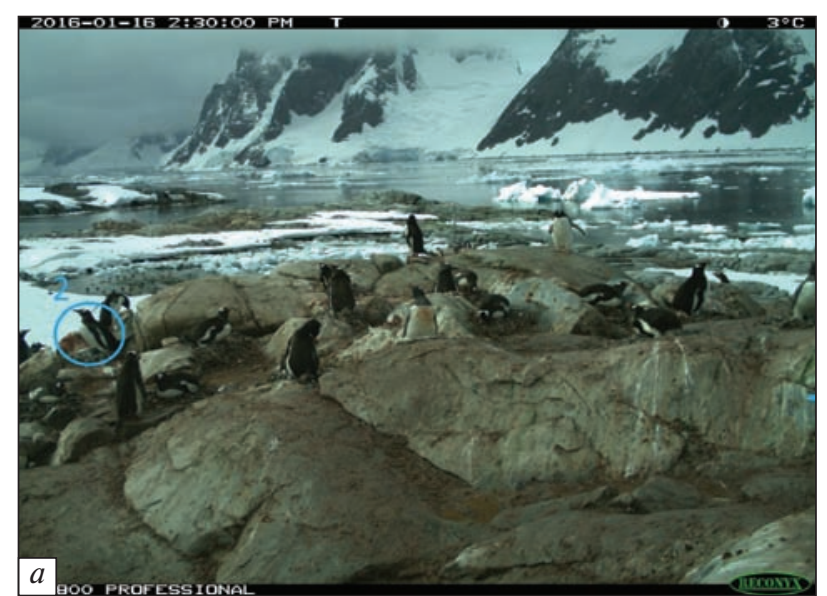

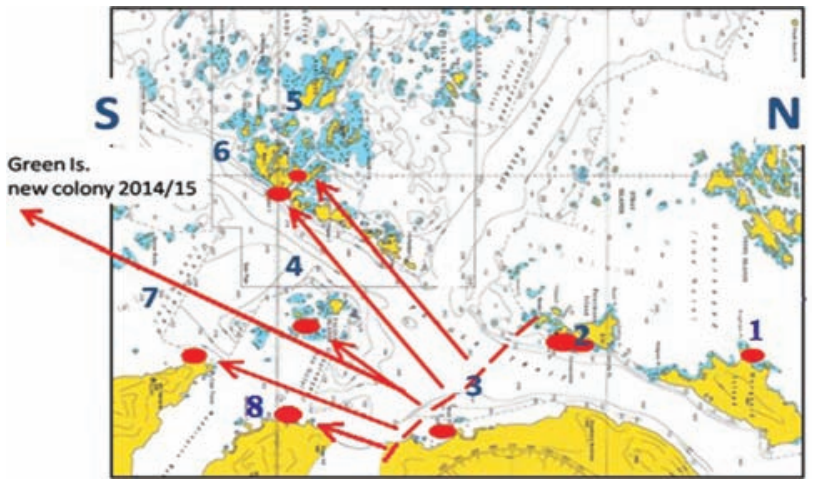

Fig. 1. Layout of expansion of the nesting colonies of Pygoscelis papua penguins in the Wilhelm Archipelago region over 1999-2017 (1, 2, 3, .. - order of the colonies forming, the arrows show direction of expansion)

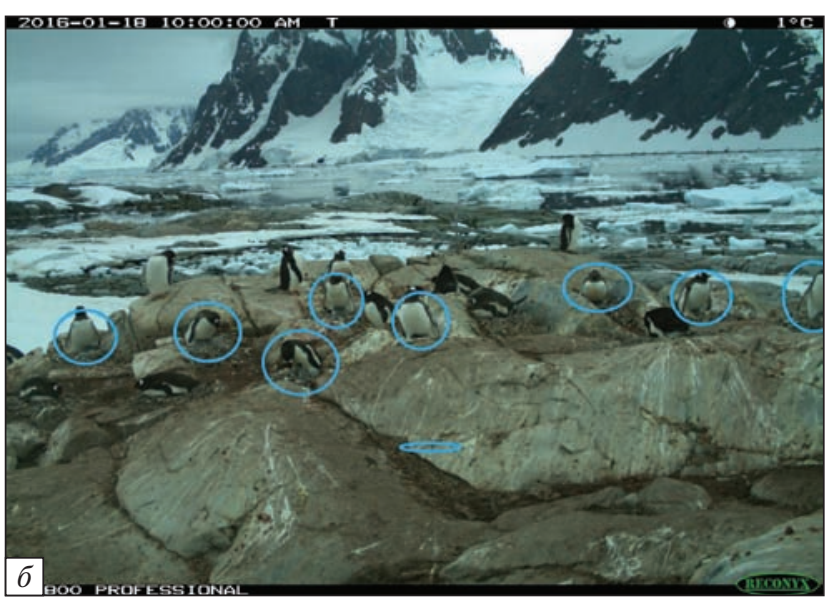

Fig. 2. Registration of the first Pygoscelis papua chick in the nest N.2 (a); Registration of Pygoscelis papua chicks at several nests in 2015/2016 summer season (Petermann Island, Camera PTI1) (b)
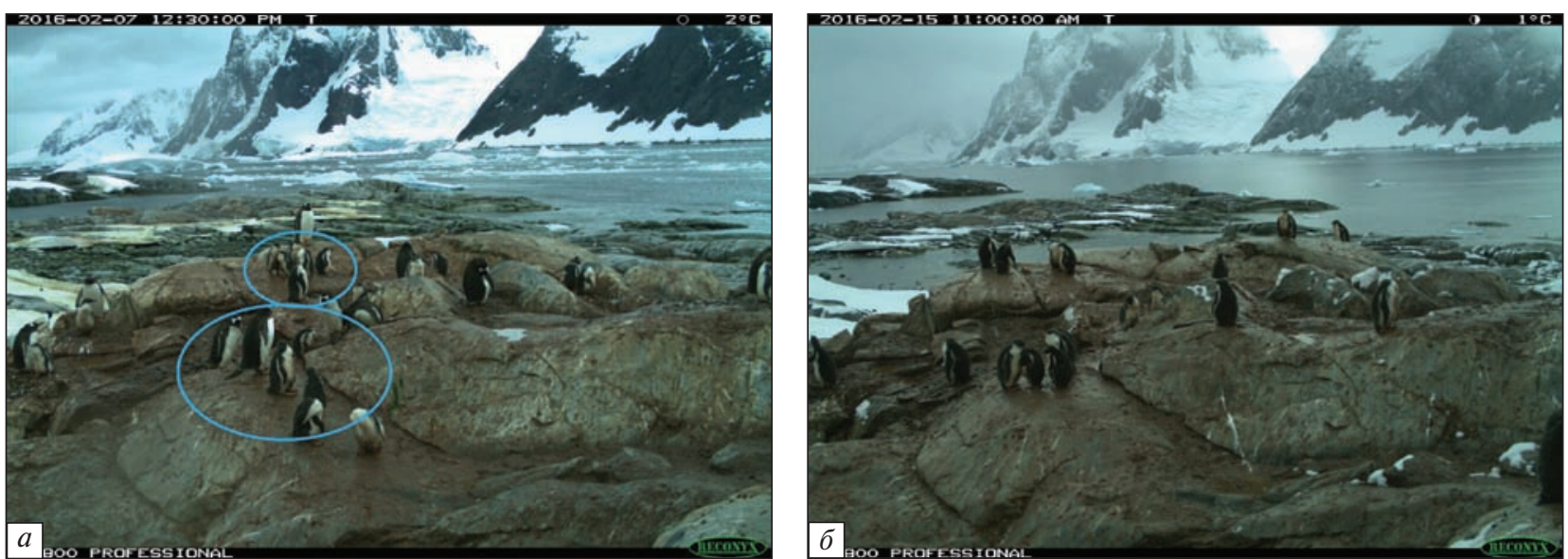

Fig. 3. Forming of Pygoscelis papua crèche (a); Chicks of Pygoscelis papua without adult birds in the nesting colony in 2015/2016 summer season (Petermann Is, Camera PTI1) $(b)$ 

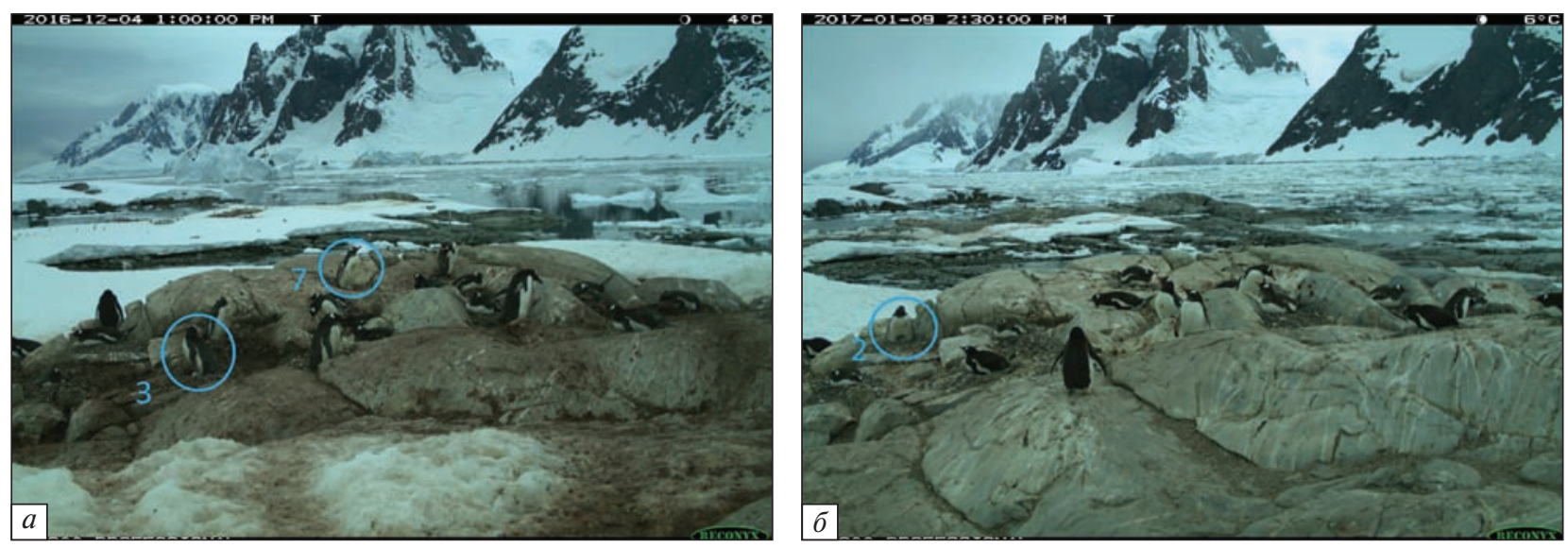

Fig. 4. Registration of the first egg laying of Pygoscelis papua in the nests N 3 and N 7 (a); Registration of the first chicks hatching in the nesting colony in 2016/2017 summer season (Petermann Island, Camera PTI1) (b)
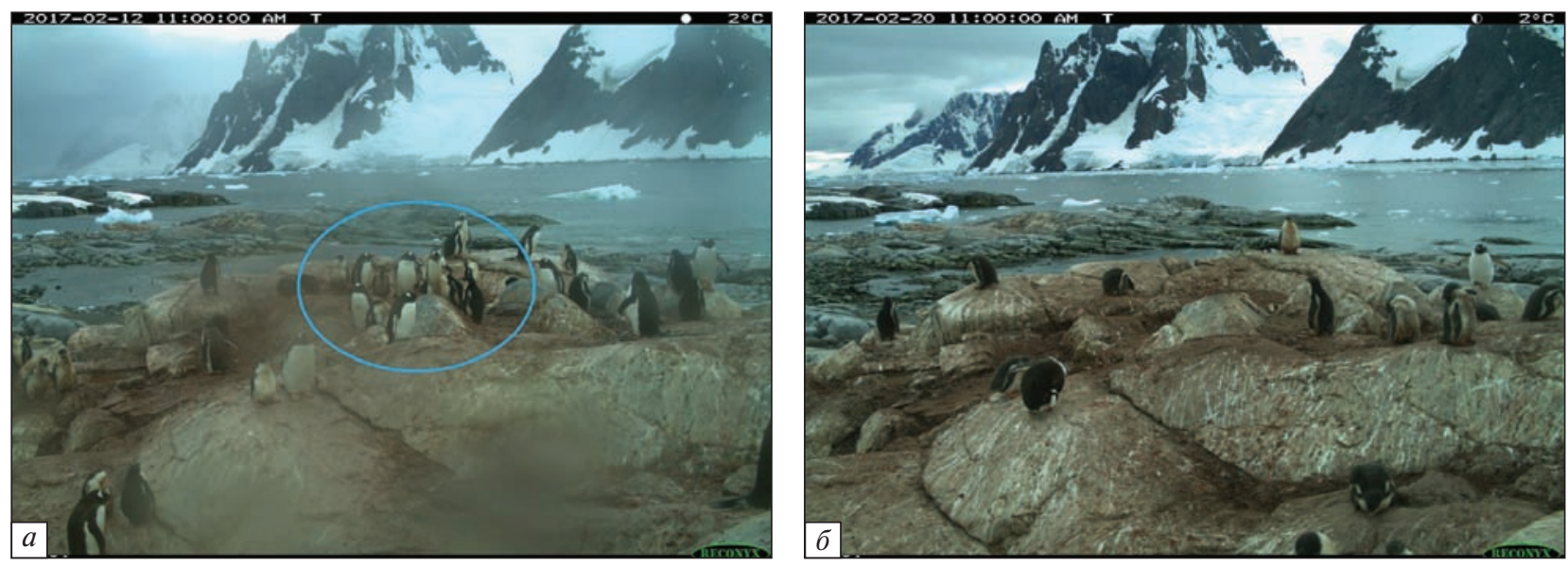

Fig. 5. Forming of Pygoscelis papua crèche in the nesting colony (a); Gentoo chicks without adult birds in 2016/2017 summer season (Petermann Island, Camera PTI1) $(b)$

system of the Wilhelm Archipelago was based on the simultaneous analysis of averaged data from automatic cameras, results of visual observations of biologists of the $20^{\text {th }}, 21^{\text {st }}$ and $22^{\text {nd }}$ UAE, and analysis of the stomach content of dead penguins, collected during $11^{\text {th }}$, $14^{\text {th }}$ and $16^{\text {th }}$ Ukrainian Antarctic Expeditions.

\section{RESULTS}

\section{Changes of the nesting area of Pygoscelis papua over the last decade}

It was established that the nesting area of $P$. papua penguins has significantly expanded southward at the beginning of the XXI century as a result of increasing

\section{4}

of annual mean temperature in more than $2.5^{\circ} \mathrm{C}$ in the Antarctic Peninsula during the XX century. This was also confirmed by results of British biologists, who showed that population of $P$. papua in this region continuously growing and its area is extending. The reproductive success of $P$. adeliae and $P$. antarcticus penguins has declined (Poncet and Poncet, 1987; Clucas et al., 2014). As a result, new nest colonies of gentoos penguins were recorded on Moot, Great Yalour, Galindez, Cape Tuxen, Cape Rasmussen and the Green Islands. The first unsuccessful attempt to form the nest colony on Galindez Island took place in 2005. In 2007 the penguins formed two viable colonies of 21 and 5 nests (at the coast area near the Vernadsky staISSN 1727-7485. Ukrainian Antarctic Journal. 2018, № 1(17) 
tion and at Cape Penguin Point, respectively) when 17 chicks successfully hatched in total. In 2008/2009 summer season 140 nests ( 212 chicks) were registered at Galindez Island. In 2009/2010 summer season the number of nests in two colonies at Galindez Island has increased to 255 nests and 209 chicks. In 2016/17 summer season the number of 2443 nests with 3791 chicks of this species was recorded at Petermann Island. There were also two large colonies with chicks on Pleneau Island (more than 500 birds) and Hovgaard Island (west coast) - more than 250 birds.

In January 2017, 1226 adult P. papua birds and 578 nests with 598 chicks were recorded in the nest colo- ny on Capes Penguin and Pigeon Point (Galindez Island). The smaller nesting colony of this species, located near buildings of the Vernadsky station, had 735 adults, 292 nests with 247 chicks. Totally in the summer season of 2016/17 on Galindez Island 870 nests of $P$. papua penguins were registered. So, over the last seven years the nest population of this species on Galindez Island increased almost 3.5 times. That is the visible tendency of the southward expansion of this specie in the breeding period, which continues to search and domesticate the new breeding areas.

In the summer season of 2017, nesting colonies of $P$. papua penguins have been expanded on the Green

Table 2. Registration of the first Pygoscelis papua penguins within the breeding colonies area and their number in places of photo registration according to cameras (2016/2017 season)

\begin{tabular}{|c|c|c|c|c|c|}
\hline \multicolumn{6}{|c|}{ Galindez Island } \\
\hline Date & GBV & Date & GPP1 & Date & GPP2 \\
\hline 19.10 .2016 & 0 & 24.10 .2016 & 0 & 24.10 .2016 & 0 \\
\hline 20.10 .2016 & 2 & 25.10 .2016 & 3 & 26.10 .2016 & 4 \\
\hline 28.10 .2016 & 14 & 28.10 .2016 & 6 & 27.10 .2016 & 15 \\
\hline 29.10 .2016 & 25 & 29.10 .2016 & 10 & 28.10 .2016 & 40 \\
\hline 30.10 .2016 & 37 & 30.10 .2016 & 22 & 29.10 .2016 & 55 \\
\hline 31.10 .2016 & 28 & 31.10 .2016 & 27 & 31.10 .2016 & 94 \\
\hline \multicolumn{6}{|c|}{ Petermann Island } \\
\hline Date & PTI1 & Date & PTI2 & Date & PTI3 \\
\hline 22.10 .2016 & 0 & 23.10 .2016 & 0 & 23.10 .2016 & 0 \\
\hline 23.10 .2016 & 1 & 24.10 .2016 & 7 & 24.10 .2016 & 1 \\
\hline 25.10 .2016 & 5 & 25.10 .2016 & 9 & 25.10 .2016 & 1 \\
\hline 27.10 .2016 & 13 & 28.10 .2016 & 22 & 27.10 .2016 & 7 \\
\hline 29.10 .2016 & 15 & 29.10 .2016 & 39 & 28.10 .2016 & 7 \\
\hline 31.10 .2016 & 18 & 30.10 .2016 & 23 & 29.10 .2016 & 19 \\
\hline \multicolumn{6}{|c|}{ Great Yalour Island } \\
\hline Date & YAL1 & Date & YAL2 & Date & YAL3 \\
\hline 19.10 .2016 & 0 & 17.10 .2016 & 0 & 20.10 .2016 & 0 \\
\hline 20.10 .2016 & 2 & 18.10 .2016 & 1 & 21.10 .2016 & 4 \\
\hline 21.10 .2016 & 8 & 19.10 .2016 & 2 & 22.10 .2016 & 25 \\
\hline 22.10 .2016 & 22 & 20.10 .2016 & 6 & 23.10 .2016 & 30 \\
\hline 25.10 .2016 & 36 & 22.10 .2016 & 23 & 25.10 .2016 & 36 \\
\hline 26.10 .2016 & 38 & 24.10 .2016 & 34 & 26.10 .2016 & 43 \\
\hline
\end{tabular}


Island (the most southern boundary of the nesting area known today), where 12 adult specimens and 14 chicks were recorded, as well as to the Antarctic Peninsula Mainland in the area of Cape Tuxen - 192 adults and 150 chicks, and Cape Rasmussen -6 adults and 3 chicks (Fig. 1). Consequently, it was found that in the beginning of the 21 st century, due to climate changes, there was a significant expansion of $P$. papua penguin colonies south of Petermann Island. In particular, there was a first expansion of $P$. papua penguins on the Galindez Island in 2007. In the summer season $2014 / 2015$, the gentoo species was expanded its nesting area to Green Island. Therefore, over the past 10 years $P$. papua was spreaded southward by almost $30 \mathrm{~km}$ and formed six new breeding colonies.

\section{Reproduction chronology of populations $P$. papua and $P$. adeliae}

The chronology of the seasonal reproduction and success of $P$. papua penguins was registered using the database of the CEMP automatic cameras over two years.

Summer of season 2015/2016. The reproduction chronology was recorded in the summer season of $2015 / 2016$ by photos when the chicks have already hatched, because the CEMP automatic cameras were installed on the islands with delay. The coupling of penguins and eggs laying were recorded visually. The first copulation has occurred on October 24 at Cape Penguin Point. As the number of nesting pairs in the colonies increased, the number of copulations reached its peak in mid-November. The first egg lay appeared in November 15 in two nests in the GPP colony and four nests - in the GBV colony. Complete lay registered in November 18. The hatching of the first $P$. papua chick was recorded in January 16, 2016 (Fig. 2,a). The average date when $P$. papua chicks hatching at some nests was January 18, 2016 (Fig. 2, b).

It should be noted that usual incubation of $P$. papua penguin lasts 34-36 days. Further north (where it is warmer), in the Falkland Islands, it can last up to 27 days (Otley et al., 2005). In our case, the long period ( 2 months) between the laying of the first egg and the hatching of the first chick does not reflect the actual incubation duration. It indicates that at the southern boundary of their nesting area the birds are in more extreme conditions for birds. Therefore, often the first laied eggs/chicks has been died because of unfavorable weather conditions and bird predators press (seagulls, skuas, and sheathbills). Thus, over the seasons 2015/16 and in 2016/17 the first eggs were deposited onto the snow and were lost, therefore penguins had to relay the eggs and chicks have hatched a month later.

The peculiar penguins' phenomenon is the formation of "crèche" (crèche - French for nursery), when chicks from different nests are grouped into the socalled "baby nursery". In the crèche adult birds take care of several chicks at once. The first formed crèche in the nest colony at Petermann Island was recorded on February 7, 2016. Since this date the number of chicks in the crèche constantly increased (Fig. 3,a). All adults $P$. papua finally left their nests on February 15, 2016 (Fig. 3, b).

Summer of season 2016/2017. The first appearance of $P$. papua penguins in the nest colony of Petermann Island was registered by cameras at the end of October 2016 - 24.10.2016 (Table 2). However, the first eggs laying in the summer season 2016/2017 was noted only on December 4, 2016, simultaneously in the nests $\mathrm{N} 3$ and $\mathrm{N} 7$ (Fig. 4, $a$ ). The first chicks in the nest colony at Petermann Island were recorded on January 9, 2017, in the nest N 2 (Fig. 4, b).

In the 2016/17 summer season, Adelie penguins have laid the first egg at Great Yalour Island on 11.6.2017, whereas the first egg laid of $P$. papua was noted on 11.11.2017 on Petermann Island. In the GBV colony the first egg laid by $P$. papua was registered one day later, on 12.11.2017. Thus, the distance between the dates of the laying is quite short. However, it was found that the intensity of eggs laying by $P$. papua was higher than by $P$. adeliae penguins. Visual observation showed that in four days after laying had started, gentoo eggs were seen in $10-15 \%$ of the nests, whereas only $1-2 \%$ of nests of $P$. adeliae. Control count (every two days since the first egg laying) of the selected group of 100 nests enabled to determine dynamics of laying: $16.11 .17-1 \%$ of nests had eggs; $18.11 .17-10 \% ; 20.11 .17-43 \% ; 22.11 .17-70 \%$; $24.11 .17-95 \% ; 26.11 .17-98 \% ; 28.11 .17-99 \%$. 
Thus, in 12 days practically the eggs had been laying and incubation started.

It was established, that the average date of chicks hatching in 10 nests on Petermann Island is 14.01.2017. The first crèche in 2016/2017 summer season of has been formed 11.02.2017 (Fig. 5, a). All adult birds left their nests 20.02.2017 (Fig. 5, b).

Usually, the clutch of $P$. papua penguin consisted of 2 eggs, although some pairs had only one egg. Threeeggs laid were quite rare (one nest at Moot Island and two nests at Petermann Island). Four-eggs laying was registered only once at Pleneau Island. The complete clutch of $P$. adeliae also consisted mainly of two eggs, although sometimes they lay from one to three eggs. For instance, two nests with three chicks were registered at Great Yalour Island and two nests at Petermann Island.

The data comparison between 2015/16 and 2016/17 seasons showed that over 2015/2016 season the average date of chicks hatching were in the mid-January (18.01.2016), which was eight days later than over the 2016/2017 season (Table 3). In our opinion this was caused by unfavorable weather conditions in the late spring. Accordingly, the terms of the chicks hatching were shifted to mid-January.

Adelie penguins were laid the first eggs at Great Yalour Island between 21.11.2016 and 6.11.2017, whereas the first eggs of $P$. papua at Petermann and Galindez Islands were registered in early December with mean date 04.12.2016 and 07.12.2017, respectively. Therefore since Petermann Island is located more northward, the first egg lay occurred three days earlier. $P$. adeliae first chicks hatching starts at Great Yalour Island two weeks earlier (25.12.2016) then at Galindez and Petermann Islands (averaged date 10.01.2017), see in Table 3. It should be noted that the first lay in the colonies and, respectively, the first chicks, were visually registered a week earlier on average. For instance, the first chicks at Galindez Island colony appeared 1-2.01.2017, but these nests were not in the scope of the automatic cameras.

We suppose that the difference in date of the clutch initiation and chicks hatching between $P$. papua and $P$. adeliae is caused by physiological peculiarities of the species and is not related to their trophic base (krill availability) in the waters of the Wilhelm Archipela-

Table 3. Averaged data from photos over the summer season 2016/2017 of Wilhelm Archipelago cameras from the CEMP Camera Network in CCAMLR Subarea 48.1

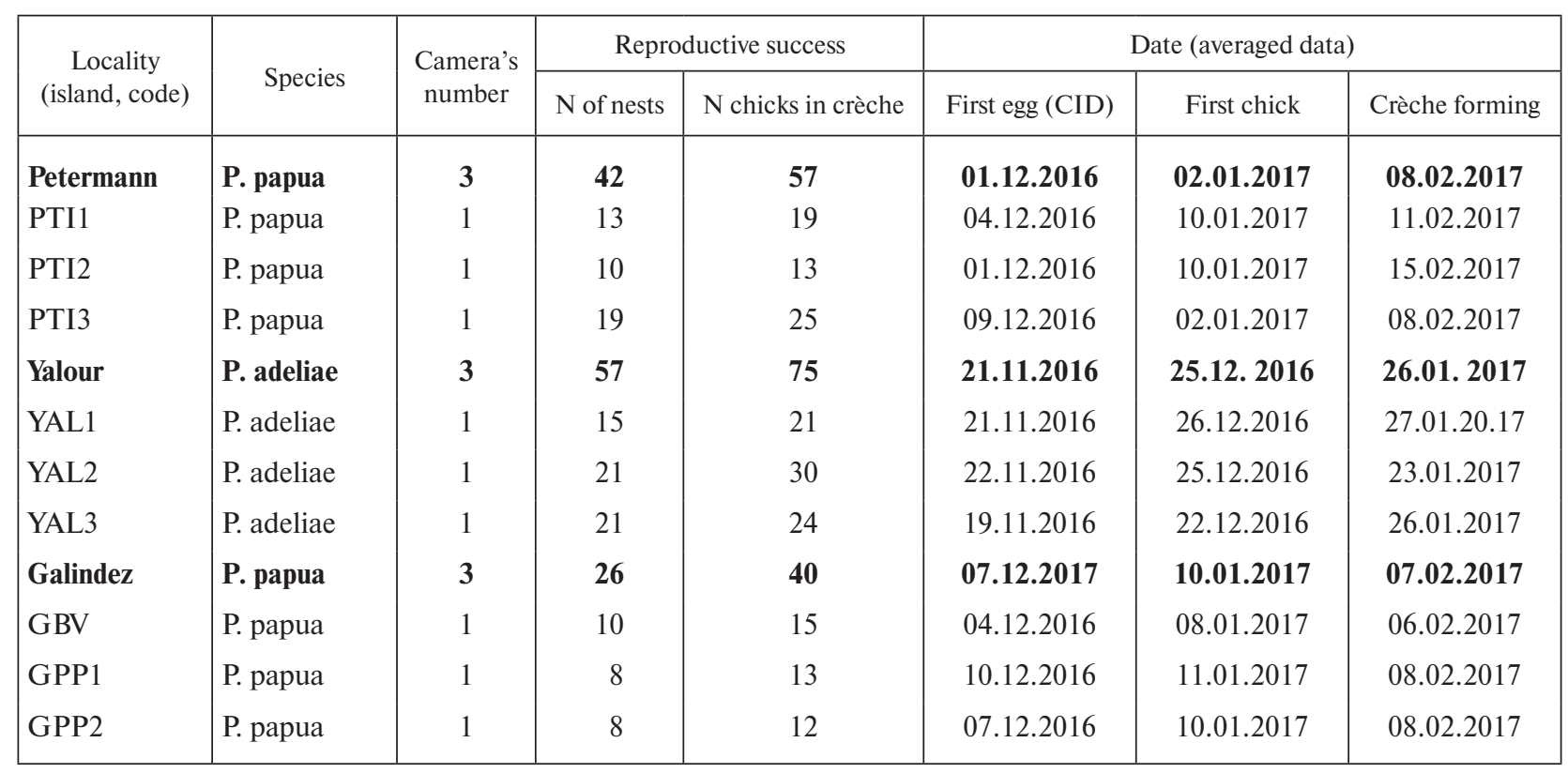

Note: CID - date of the first egg laying. In the table this date when the first egg is visible in the image of the corresponding camera 
go, as the forage areas of all nest colonies on the considered islands are overlapped. However, date of the chicks' transition to crèche differed from the previous results. According to the automatic observation results, the last penguins who create crèche were $P$. $p a$ pua on Petermann Island - on 11.02.2017, whereas $P$. adeliae already formed crèches in 26.01.2017. Gentoo penguins formed crèche 07.02.2017 in the colonies on Galindez Island. Forming of crèche gives ability for both parents to go for food and, thus, the daily consumption of krill nearby the nesting colony increases. Adults feed within $20 \mathrm{~km}$ from the nest colony, leave in the morning and come back in the evening. The time spent for feeding increases as the chicks grow.

Table 4. The breeding dynamics of the penguin $P$. papua during the breeding seasons of 2003-2017 on Petermann Island

\begin{tabular}{|c|c|c|c|}
\hline Season & $\begin{array}{c}\text { Number } \\
\text { of nests }\end{array}$ & $\begin{array}{c}\text { Number } \\
\text { of chicks }\end{array}$ & $\begin{array}{c}\text { Ratio } \\
\text { chicks/nests }\end{array}$ \\
\hline $2003 / 04$ & 2119 & 3088 & 1,46 \\
$2004 / 05$ & 2232 & 2711 & 1,21 \\
$2005 / 06$ & 2438 & 3313 & 1,36 \\
$2006 / 07$ & 2293 & 3327 & 1,45 \\
$2009 / 10$ & 2443 & 3791 & 1,55 \\
$2010 / 11$ & 2898 & 4260 & 1,47 \\
$2014 / 15$ & 2941 & 4638 & 1,58 \\
$2015 / 16$ & 3499 & 3041 & 0,87 \\
$2016 / 17$ & 1852 & 2353 & 1,27 \\
\hline
\end{tabular}

Table 5. The breeding dynamics

of the penguin $P$. adeliae during the breeding seasons of 2003-2017 on Petermann Island

\begin{tabular}{|c|c|c|c|}
\hline Season & Nests & Chicks & $\begin{array}{c}\text { Ratio chicks/ } \\
\text { nests }\end{array}$ \\
\hline $2003 / 04$ & 509 & 723 & 1.42 \\
$2004 / 05$ & 502 & 575 & 1.15 \\
$2005 / 06$ & 479 & 589 & 1.23 \\
$2006 / 07$ & 410 & 457 & 1.11 \\
$2015 / 16$ & 261 & 360 & 1.37 \\
$2016 / 17$ & 213 & 246 & 1.15 \\
\hline
\end{tabular}

\section{8}

\section{Reproductive success of $P$. papua and $P$. adeliae populations}

Analysis of data regarding the nesting colony of $P$. papua at Petermann Island over the last 14 years enables to conclude that reproduction success of this species varied from 0.87 to 1.58 chicks per nest with the average number 1.26 chicks per nest (Table 4 ).

$P$. adeliae chicks number per nest varied from 1.11 to 1.42 in the colony on Petermann Island (Table 5). The average number is 1.21 , which is close to those for gentoo penguins. At the same time, the second colony of $P$. adeliae on Petermann Island practically disappeared in 2017. One nest only was registered among the dominating nests of $P$. papua, while in 2014 season two nest colonies of this species were registered (Smagol, 2016). In spite of similar reproductive success, $P$. papua penguins prevail by the number of nest colonies and total number of breeding pairs. This trend in the Wilhelm Archipelago region has been traced since 1958, when British researchers pointed that in 1982 the number of $P$. adeliae nesting pairs in the colony of Great Yalour Island decreased twice and continued to decrease (Poncet and Poncet, 1987). Thus, over the 2003/2004 and 2007/2008 seasons at Petermann Island P. adeliae population decreased by $29 \%$, where as $P$. papua population increased by $27 \%$ (Lynch et al., 2010).

However, despite this general trend, some pairs of $P$. adeliae of reproductive age form small nesting colonies at new territories. For example, in the 2016/2017 season new colony of this species was discovered on islands of the Berthelot group (172 adults and 3 chicks). Because of heavy ice conditions, the biologists had been reaching the colony after the chicks have molted and independently feeded in the ocean.

Totally, over the 2015/2016 season 13 nests of $P$. papua were recorded by cameras at the investigated area (Petermann Island, Camera PTI1). Among them three nests were deserted. Therefore the relative success of $P$. papua nesting in the model area is about $77 \%$ (number of chicks -17 and 13 of them survived and have grown).

Over 2016/2017 summer season 13 nests were studied with camera PTI1. None of them were deserted. 
Consequently, the relative success of nesting for the camera observed area of the breeding colony $P$. papua at Petermann Island in the 2016/2017 summer of season was $100 \%$. In general, in the breeding colony P. papua at Petermann Island camera PTI1 observed 20 eggs from which 14 chicks hatched and survived. Therefore, the relative reproductive success for the camera studied area of the breeding colony P. papua in the 2016/2017 summer season was $70 \%$.

Comparison of the nesting success of $P$. papua in the camera observed area at Petermann Island in the 2015/2016 and 2016/2017 summer seasons showed their difference. The nesting success over 2016/2017

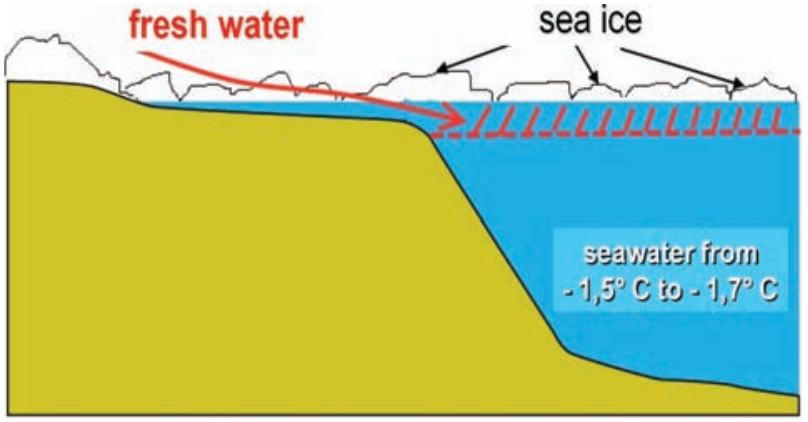

conditions: temperature $\left(+\mathrm{C}^{\circ}\right)$; no south wind

Fig. 6. Scheme of ice formation ( $8-10$ points) in the Argentine Islands area
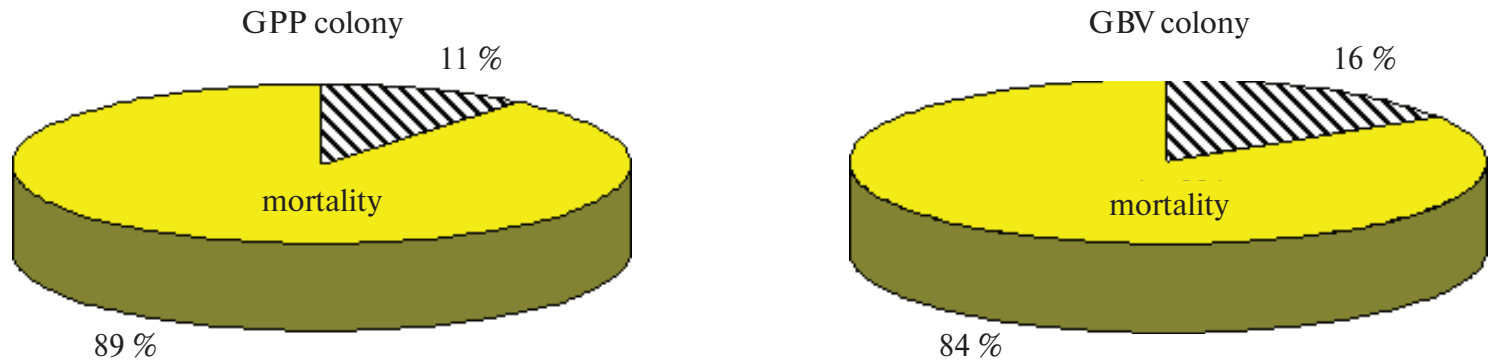

Fig. 7. Survival of Pygoscelis papua chicks in the GPP and GBV colonies at Galindez Island over 2011/2012 season

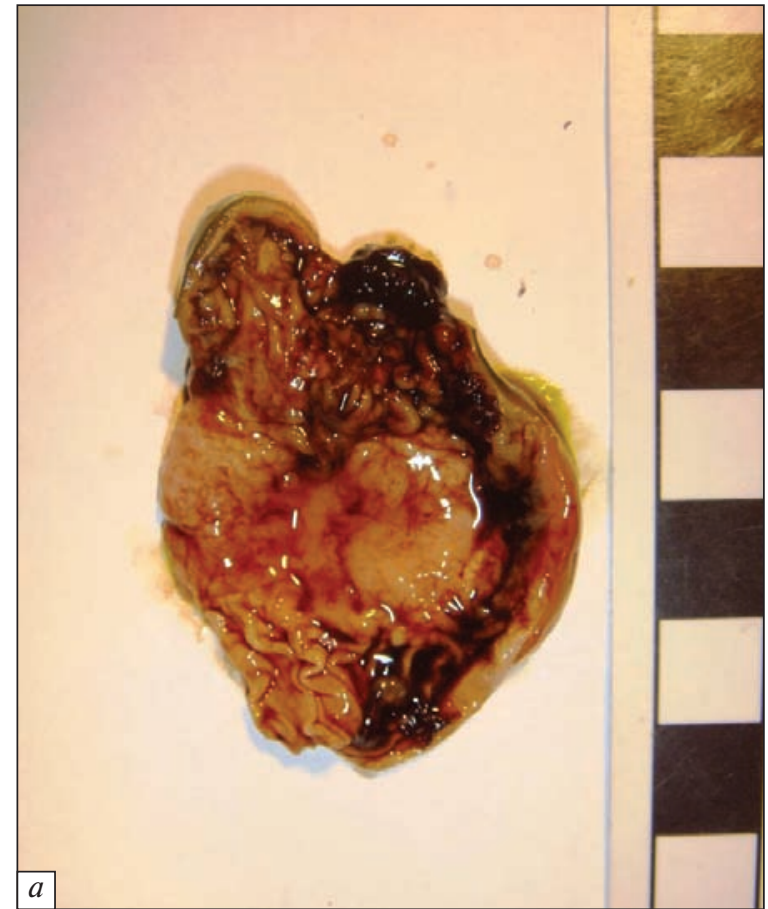

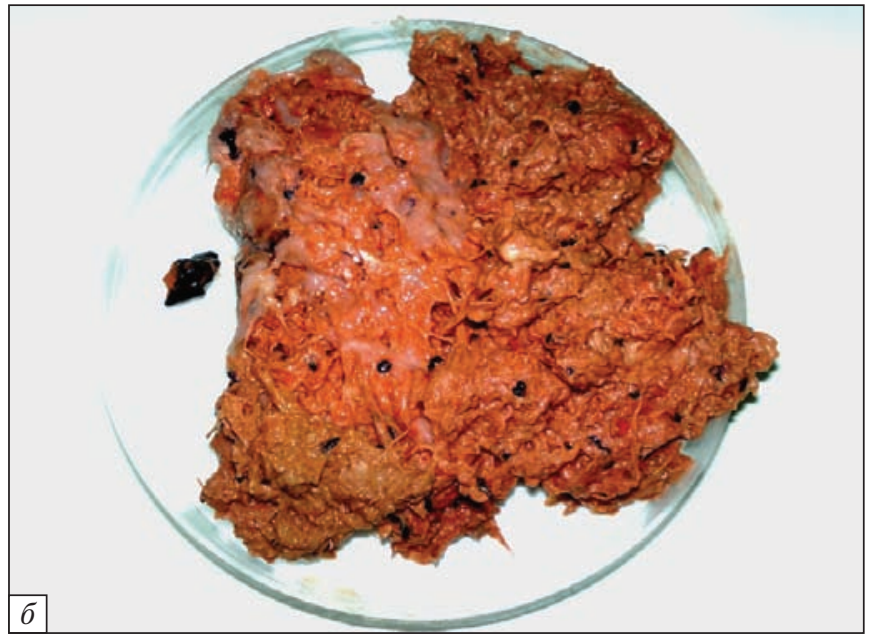

Fig. 8 . The stomach content of the dead Pygoscelis papua penguin from the GPP colony in unfavorable and favorable summer seasons: $a-$ empty chick stomach (2011/12 season); $b$ - adult bird's stomach filled by krill (2009/10 season) 


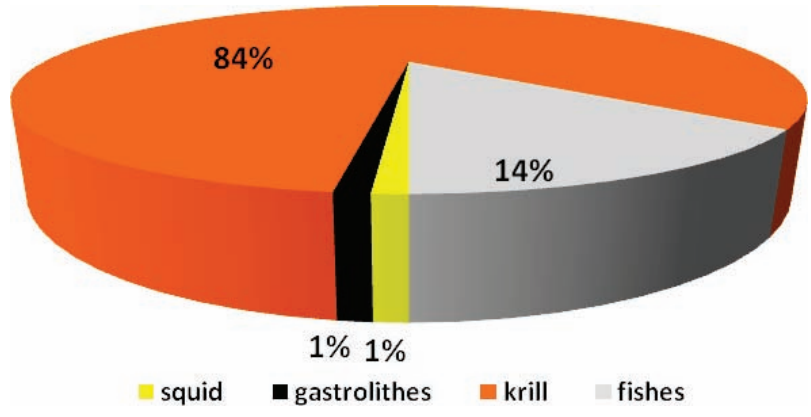

Fig. 9. Stomach content of Pygoscelis papua at the Argentine Islands area

summer season was maximal $(100 \%)$ whereas over $2015 / 2016$ season was equal $77 \%$, when adverse weather conditions created breeding problems at the start laying eggs of the penguin. On the contrast, the re- productive success was higher $(77 \%)$ over $2015 / 2016$, probably primarily due to the forage availability krill abundance nearby Petermann Island area.

\section{The impact of krill abundance on reproductive success of $P$. papua populations}

We analyzed the original data collected from December 2011 to February 2012 to reveal the impact of krill abundance on the reproductive success of $P$. papua populations. Over the considered period the ice conditions (8-10 points of ice index) in the Argentine Islands Archipelago and Penola Strait were unfavorable (Dykyy, 2013; Dykyy, 2016). That was caused by absence of the south wind, which usually moved the sea ice into the open ocean, in addition to abnormal-

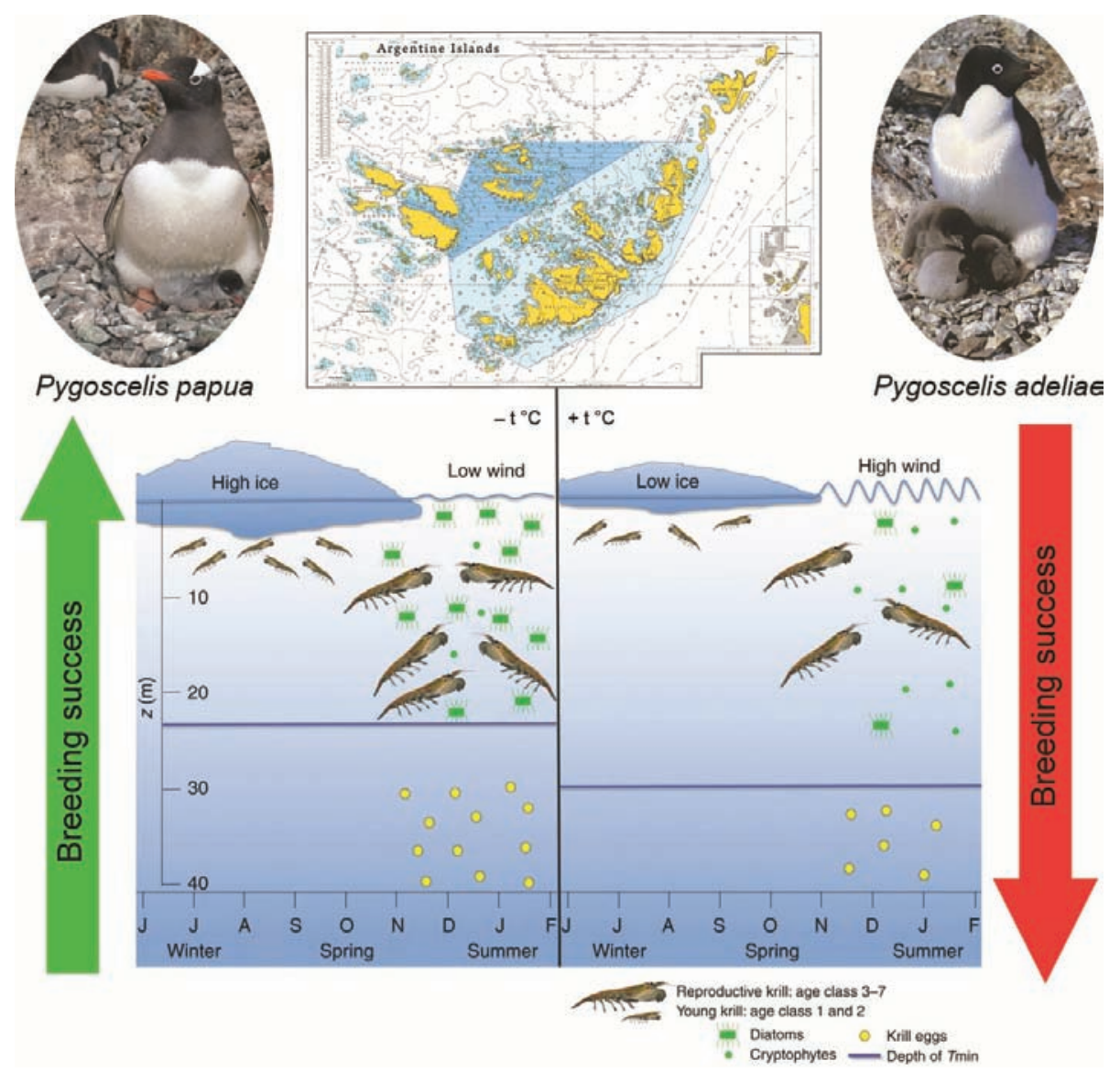

Fig. 10. Qualitative model of possible changes in the ecosystem based on krill Euphausia superba in the Argentine Islands area (modified from Saba et al., 2014) 
ly low summer temperatures of the seawater $\left(-1.5^{\circ} \mathrm{C}\right.$... $\left.-1.7^{\circ} \mathrm{C}\right)$. However, the average air temperature was above zero, which led to the snow melt. As a result, fresh melting water flowed into the ocean and formed the upper layer of seawater, thus this upper layer froze because of low temperature of the underlying layer. The newly formed fresh water ice fastened the sea ice underneath, forming a kind of a "basement" (Fig. 6). Such an isolation of the water area of archipelago by the sea ice had led to the decrease of the marine birds and mammals density within the Argentine Islands, and significantly affected reproduction of the abundant P. papua at the archipelago.

Particularly, we observed high mortality of the newborn chicks at Galindez Island because of starvation, as adult birds could not reach the open water, they left nests with chicks. Thus, colony at Cape Penguin Point were consisted from 332 nests in November 2011 and in December only from 133.49 nests of 136 were remained in the colony near Vernadsky station.

In that time number of living nests decreased almost three times. On Penguin Point Cape from 191 chicks survived only 21, and in the colony near Vernadsky station 12 chicks survived from 74 . On the whole, the mortality rate of $P$. papua chicks in the 2011/2012 summer season was $84-89 \%$ (Fig. 7). Dissection and analysis of stomachs content of 60 different age chicks confirmed that their death was caused by starvation. All stomachs were empty. Sometimes in the stomachs of dead chicks occurred gastrolithes, which because of big size caused intestinal obstruction. Adult birds fed the chicks by gastrolithes (instinctive feeding) having their own stomachs empty (Dykyy et al., 2013; Dykyy, 2016).

It should be noted that underwater surveys, carried out by seasonal biologists Dr. A. Utevsky and D. Shmyrev in the water area near Galindez Island, showed some krill abundance, which, however, was not available for all sea birds because of the ice covering. Thus, unfavorable ice condition over the abnormal 2011/2012 season, which caused isolation of food in the water area of the archipelago, significantly affected the survival of sea birds and negatively affected reproduction of $P$. papua. Similar situation was occurred in the same colony in the 2015/2016 summer season. However, the starvation and mass death of $P$. papua chicks at that time was caused by the absence of krill in the water area of the islands, which, in turn, was caused by intensive and prolonged (January - February 2016) water "bloom" by diatoms. Therefore, from 1194 birds' chicks have survived only 530 . The mortality of chicks in area of the GPP colony in this season was $55.6 \%$. Another case of catastrophic mortality of the $P$. adeliae breeding colony in the 2016/2017 summer season occurred in East Antarctica (Petrels Island), where in a colony of 18,000 nesting pairs survived only 2 chicks, all others died from starvation because of lack of their main food object krill due to climate change in the region (Slezak, 2017). Particularly, in 2010, as a result of destruction of the Mertz glacier, the iceberg fragment of size 80 by $40 \mathrm{~km}$ was separated at the distance of $250 \mathrm{~km}$ from Petrels Island. This significantly affected the ocean currents and ice processes in this region. As a result, unfavorable ice conditions forced adult penguins to feed over a long distance (more than $100 \mathrm{~km}$ ) from the colony without being able to feed their chicks in time.

The study of the stomach contents of the P. papua dead chicks indicates that the main food of these birds is krill, though small pieces of the Pleurogramma antarcticum ice fish occurred in the stomach. The stomach of the dead chicks on January 18, 2010 was completely filled by krill. The mass of the stomach contents was $69.9 \mathrm{~g}$, of which $6.51 \mathrm{~g}$ were gastrolithes and fragments of fish bones. Stomach of the dead adult penguin on January 21, 2010 was filled on $100 \%$ by krill (Fig. 8). Weight of the stomach was $8.65 \mathrm{~g}$, without gastrolithes.

Adult birds feed mainly on krill and fish, diving to the depth of $100 \mathrm{~m}$. In the northern waters $P$. papua feed mainly on fish, crustaceans form less than half of their ration. Nearby the Antarctic Peninsula, krill forms almost $85 \%$ of this species diet, and fish - about $14 \%$ (Fig. 9). Over our studies we note that P. papua penguins are eating mollusks - the Antarctic limpet and chicks feeding on octopus. Adult birds swallowed the whole limpet. Probably limpet shells also serve as, swallowed by birds to improve grinding of the krill exoskeletons in the stomach (Dykyy et al., 2011/12).

On the whole, it is known that the entire $P$. adeliae penguin population in Antarctica, estimated as compris- 
ing 2370000 breeding pairs, can consume 1500 million $\mathrm{kg}(1,500,000$ metric tons) of krill, 115 million $\mathrm{kg}$ (115,000 metric tons) of fish, and 3,500,000 kg (3,500 metric tons) squid each year (Lynch et al., 2010).

Thus, $P$. papua's food spectrum was shown to be lesser (krill, squid) than in $P$. adeliae - mainly krill, as well as squid and small fishes. It has been found in the region of the Wilhelm Archipelago that krill is the main component of the diet of both species over the spring-summer period. Taking into account that among seven penguin species occurring within the Wilhelm Archipelago, the most numerous are $P$. papua and $P$. adeliae, these species should be used as an "indicators species" for assessment of distribution and abundance of krill in the region.

\section{Key elements of the model}

On the base of the simultaneous consideration of the averaged data from automatic cameras and the results of visual observation of the biologists-winterers, we developed the model key elements for qualitative and quantitative analysis of the changes in the krill-based ecosystem of the Argentine Islands (as part of Wilhelm Archipelago).

This model of the ecosystem changes in the Argentine Islands area will be important in predicting biocenosis changes in the Western Antarctic over a long period or at climate change. The main idea of the research consists in simultaneous study of the breeding chronology and success of $P$. papua and $P$. adeliae penguins as the main consumers of Antarctic krill Euphausia superba.

Understanding of the mechanisms of the climate change impact on some trophic levels in the food web is essential for determination of the ecosystem's response. In order to develop the model for qualitative and quantitative change of the krill-based ecosystem of the Argentine Islands area, we used as a basis the study of the phytoplankton and krill populations' response to the climate change in the region of the Antarctic Peninsula, carried out for 20 years by US specialists at Palmer Antarctic Station (Saba et al., 2014). Palmer Station is located $50 \mathrm{~km}$ northward from the Argentine Islands, which enables to compare the re-

\section{2}

sults collected by the Palmer Long Term Ecological Research Program (PALLTER), determine how large-scale climate and local abiotic factors affect phytoplankton, zooplankton and predators - consumers of krill along the coast of the Antarctic Peninsula. It was found that the positive anomalies in chlorophyll $a(\mathrm{chl}-a)$ at Palmer station, occurring every 4-6 years, are limited by the physical processes of the previous winter/spring and negative phase of water temperatures. Favorable conditions for phytoplankton included increasing of amount and duration of winter ice, reducing winds in spring / summer, and increasing the steady water temperature by increasing the density gradients associated with salinity. Years of positive chlorophyll $a(\mathrm{chl}-a)$ anomalies are associated with the initiation of a strong krill cohort next summer, which manifests itself in the diet of $P$. papua and $P$. adeliae penguins, and in turn shows close trophic relationship. The predicted climate change can have a significant negative impact on phytoplankton biomass, on the growth of the krill population and predators of the upper trophic level in this coastal Antarctic ecosystem (Ainley, 1998; Vaughan et al., 2003; Ducklow et al., 2007; Montes-Hugo et al., 2009; Trivelpiece et al., 2011).

Consequently, the key elements of the model for qualitative and quantitative change in the ecosystem of the Argentine Islands, based on the krill Euphausia superba are the sexually mature specimens of $P$. papua and $P$. adeliae, which are "indicator species" of the distribution and abundance of krill in the region. The model is based on krill as a key species in the ecosystem of the Southern Ocean (Fig. 10). According to CCAMLR, the biomass of one species $E u$ phausia superba in the South Ocean is approximately $379,000,000$ tons, more than the biomass of all people on the planet. Every year whales, seals, penguins, squids and fishes eat more than half of this biomass, which is restored through reproduction and subsequent growth of the krill population. Krill demonstrates expansive daily vertical migration, thus providing predators with food at night near the surface, and at daytime - at a depth (Hamner et al., 2000; Fraser et al., 2003). The size of the krill population is very variable, and the observed changes, apparently, 
are largely due to how young krill is added to the population annually. This can be owing to changes in the presence and thickness of sea ice, which raises the issue of influence of abiotic factors (water temperature, air, wind presence, etc.) due to climatic changes (Nicol, 2000; Schofield et al., 2010).

Thus, as it is evident from the proposed quality model, the stability of low temperatures, both water and air, including slow winds, can contribute to the presence of stable and thick sea ice layer, which is a prerequisite for successful breeding, development of krill larvae and, ultimately, the presence of its main feeding objects diatoms and cryptophytes. All this leads to the rapid growth of the E. superba population. The result can be an increase of the breeding success of the main Antarctic nesting species $P$. papua and $P$. adeliae and growth of their populations. Conversely, ascending temperature can lead to decline in the krill population, which negatively affects the reproduction of these penguins in the ecosystem of the Argentine Islands (Fig. 10). It should be noted that the presence of large stock of krill, which is not available for penguins due to ice cover, do not guarantee the success of reproduction and high reproductive success in nest colonies. Such situation occurred in the 2011/2012 summer season when mortality of $P$. papua chicks ranged from $84 \%$ to $89 \%$. However, the real relations are not so direct and obvious, and depend on many factors, which in turn require a long-term monitoring of breeding colonies and more detailed research.

The qualitative model based on observations over several successive breeding seasons (5-10), will help to predict the response of the seabird species populations' future changes in the Antarctic environment. This will enable further development of recommendations for mitigation the effects of global warming and conservation of the Antarctic environment, as issue of international relevance. Based on the results of our work, we completed the protocols for research of breeding populations of $P$. papua and $P$. adeliae penguins in the CCAMLR Subarea 48.1 in the CEMP format and presented to the CCAMLR in the form of documents over the national report of Ukraine to the Working Group on Ecosystem Monitoring and Management (WG-EMM) on June 19, 2016 and June 26,
2017 (Dykyy, 2016; Milinevsky et al., 2016, 2017a, 2017b; Lutsenko, 2017).

\section{CONCLUSIONS}

It was established that in the beginning of the XXI century the nest colonies of $P$. papua penguins were expanded southward of Petermann Island. The first expansion of $P$. papua on Galindez Island was in 2007. Until 2014/2015 summer season, the gentoo species has expanded nesting area to Green Island and moved southward almost for $30 \mathrm{~km}$ over the past ten years. Six new breeding colonies were formed. $P$. papua is more ecologically plastic species in comparison with P. adeliae. Gentoo penguins are more resistant to the high temperatures. Besides that gentoo penguin has higher reproductive intensity and reproductive dynamics, hence the number of new generations of $P$. papua is higher than in other species of penguins for this breeding area. This was confirmed by studies with applying of molecular techniques to assess the demographic history and structure of the genus Pygoscelis populations under the climate change (Clucas et al., 2014).

It has been shown that $P$. papua's food spectrum is more limited (krill, squid) than of $P$. adeliae - mainly krill, as well as squid and small fishes. In the Argentine Islands Archipelago, krill is the main feeding source for both species gentoo and Adelie in the springsummer period. Taking into account that among seven penguin species occurring within the Wilhelm Archipelago, the most numerous are $P$. papua and $P$. adeliae, these species should be used as an "indicator species" of krill distribution and abundance in the region and for its stock assessment. It was established that the nesting success of $P$. papua on the CEMP cameras model area at Petermann Island in the 2016/ 2017 summer season is about $100 \%$, unlike the 2015/ 2016 season $(77 \%)$ when weather conditions at start of the eggs laying were unfavorable. Comparative analysis showed that reproductive success of $P$. papua was higher in the 2015/2016 summer season ( $77 \%$ ) than in the following season (70 \%), mainly due to sufficient forage base, presence and availability of krill in the area of Petermann Island. The high reproductive success rate of $P$. papua (the ratio of the chicks num- 
ber to the nest number), which has increased significantly over the last 15 years from 1.21 to 1.55 , indicates quite high quality and sufficient forage base in the area of the Wilhelm Archipelago. The exception was in 2015/2016 season (0.87), when many chicks had died because of low abundance of krill as a result of the water bloom. Taking into account that the krill is in the base of the trophic pyramid of the Antarctic ecosystem and it is highly sensitive to the sharp water warming, it serves as indicator of climate changes' impact on the krill-based ecosystem. Therefore, the qualitative model of possible changes in the ecosystem elements (penguins) of the Argentine Islands, based on krill E. superba, will enable to predict the reaction of sea birds populations to future changes in the Antarctic environment. This will contribute to mitigate the effects of global warming and conservation of the Antarctic environment, which is an issue of transnational concern.

The support and development of research on penguin breeding colonies using the CEMP camera network and the provision of the research results to the CCAMLR enables realistic assessment of the krill population's state in CCAMLR Subarea 48.1 and to use these results to develop a strategy for management and exploitation of marine living resources. Particularly, the results of this work could be used in the preparation of proposals for the management of the krill commercial stock fishery (E. superba) and Patagonian toothfish (Dissostichus eleginoides) fishery in Antarctica by the State Agency of Fisheries of Ukraine. This scientific research results could be taken into account by CCAMLR Countries in discussion the quotas for fishery and management of krill fishery in CCAMLR Subarea 48.1.

Acknowledgments. The authors thank the CEMP Camera team led by Jefferson Hinke and its members George Watters, Mercedes Santos, Malgozata KorczakAbshire, Andres Barbosa, Collin Southwell and Louise Emmerson for their initiative and project support, as well as valuable advice on our work. We sincerely thank Andriy Utevsky, Dmitriy Shmyrev, Ivan Parnikoza and all winterers at Vernadsky station who assisted in the maintenance of the cameras. The financial support of our study and expeditions was provided by the State In- stitution National Antarctic Scientific Center, Ministry of Education and Science of Ukraine.

Information about grant support. The technical support of the CEMP Cameras project has been funded by the Commission of the Conservation of Antarctic Marine Living Resources (CCAMLR) with the support and coordination of the CCAMLR Secretariat.

\section{REFERENCES}

1. Afanasev, S.O. 2006. Struktura biotychnych ugrupovan ta otsinka ekologichnogo statusu richok baseinu Tysy [The structure of biotic groups and assessment of the ecological status of the rivers basin Tisza]. Kiyv: Inertechnodruk.

2. Ainley, D.G. 1998. Variation in foraging patterns of Adélie penguins to changing pack-ice conditions. Polar Biology, 20, 311-319.

3. CCAMLR Ecosystem Monitoring Program. Standard Methods. 2014. Available online: www.ccamlr.org/en/document/ publications/ccamlr-ecosystem-monitoring-programstandard-methods

4. Chesalin, M.V. 2007-2008. Long-term changes in populations of birds near Ukrainian Antarctic station «Akademik Vernadsky». Ukrainian Antarctic Journal, 6-7, 110118. Available online: http://uaj.uac.gov.ua/sites/default/ files/documents/UAJ_N_6-7_110-118.pdf

5. Chesalin, M., Naveen, R., Lynch, H., Bullock, I., Rider, M., Miller, A., Forrest, S., Dagit, R., Dykyy, I., Timofeyev, V. 2009. Long-term changes in populations of seabirds on Petermann Island and surrounding islands in Graham Land, Antarctic Peninsula. Marine Ecological Journal, 8 (3), 5-13. Available online: https://dspace.marine-research.org/bitstream/299011/1017/1/Chesalin_Penguin_ Manuscript_MEJ.pdf

6. Clucas, G., Dunn, M., Dyke, G., Emslie, S.D., Levy, H., Naveen, R., Polito, M., Pybus, O.G., Rogers, A.D., Hart, T. 2014. A reversal of fortunes: climate change 'winners' and 'losers' in Antarctic Peninsula penguins. Scientific reports, 4, 5024. DOI: 10.1038/srep05024

7. Croxall, J.P., Kirkwod, E.D. 1979. The distribution of penguins on the Antarctic Peninsula and islands of the Scotia Sea. British Antarctic Survey. Bulletin, 68, 71-81.

8. Directive 2000/60/EC of the European Parliament and Council of 23 October 2000 establishing a framework for Community action in the field of water policy. Official Journal of the European Communities, L 327, 22/12/2000, 72.

9. Ducklow, H.W., Douglas, K.B., Martinson, G., Quetin, L.B., Ross, R.M., Smith, R.C., Stammerjohn, S.E., Vernet, M., Fraser, W. 2007. Marine ecosystems: The West Antarctic Peninsula. Phil. Trans. R. Soc. London B. Biol. Sci., 362 (1471), 67-94.

ISSN 1727-7485. Ukrainian Antarctic Journal. 2018, № 1(17) 
10. Dykyy, I. 2013. The Effect of abiotic factors on the reproduction of seabirds on the Argentine Islands. Youth and Progress of Biology: abstracts book of the VII International Scientific Conference of Students and PhD Students. Lviv, 16-19 April, 2013, 7-8. Available online: http:// bioweb.lnu.edu.ua/postup/pdf/pimb-tezi-2013.pdf

11. Dykyy, I.V., Salganskiy, O.O., Janko, K. 2013. The Effect of anomal season of antarctic summer on the reproduction of Gentoo penguins (Pygoscelis papua) near Akademik Vernadsky station. Internationalization of Antarctic research - way to spiritual unity of humanity:absrtracts VI International Antarctic Conference. Kyiv, 15-17 May, 2013, 59-63.

12. Dykyy, I.V. 2016. The effect of abiotic factors on the reproduction of seabirds on the Argentine Islands. Document CCAMLR № WG-EMM-16/59, 19 June 2016, 1-7.

13. Dykyy, I., Tsaryk, Y., Shydlovskyy, I., Trokhymets, V., Holovachov, O. 2011-2012. Cenotic connections land biota Islands Western Antarctic. Ukrainian Antarctic Journal, 10-11, 239-256.

14. Fraser, W.R., Hofmann, E.E. 2003. A predator's perspective on causal links between climate change, physical forcing and ecosystem response. Mar. Ecol. Prog. Ser, 265, $1-15$. DOI $10.3354 /$ meps 265001

15. Gain, R.A. 1914. Oiseaux antarctiques. 2e expédition antarctique française (1908-1910), Paris, Masson et Cie.

16. Hamner, W.M., Hamner, P.P. 2000. Behavior of Antarctic krill (Euphausia superba): schooling, foraging, and antipredatory behavior. Canadian Journal of Fisheries and Aquatic Sciences, 57, 192-202.

17. Hinke, J.T., Barbosa, A., Emmerson, L.M., Hart, T., Juáres, M.A., Korczak-Abshire, M., Milinevsky, G., Santos, M., Trathan, P.N., Watters, G.M., Southwell, C. 2018. Estimating nest-level phenology and reproductive success of colonial seabirds using time-lapse cameras. Methods Ecol Evol., 1-11. DOI: 10.1111/2041-210X.13015

18. Loparev, S.A. 2003. Irregular breeding, migratory-wintering and vagrant species of the ornithofauna of Graham Coast of Antarctic Peninsula. Berkut, 12, (1-2), 50-56. Available online: http://www.aetos.kiev.ua/berkut/berkut 12/ fau- na12-8.pdf

19. Lutsenko, D., Milinevsky, G., Savitsky, O., Simon, A., Dykyy, I., Telipska, M., Lytvynov, V. Pshenichnov, L. 2017. CEMP Fund cameras and satellite transmitter projects in areas of Ukraine responsibility: state and preliminary results. Document CCAMLR №SC-CAMLR-XXXVI/BG/34, 16 September 2017, 1-5.

20. Lynch, H.J., Fagan, W.F., Naveen, R. 2010. Population trends and reproductive success at a frequently visited penguin colony on the western Antarctic Peninsula. Polar Biology, 33(4), 493-503. DOI 10.1007/s00300-009-0726-y.

21. Milinevsky, G., Dykyy, I., Khoetsky, P., Veselsky, M., Utevsky, A., Shmyrov, D., Parnikoza, I., Lutsenko, D.,
Savitsky, O. 2016. CEMP camera installations by Ukraine at the Galindez, Petermann and Yalour Islands penguin colonies as a part of CEMP Fund project 'Establishing a CEMP camera network in Subarea 48.1'. Document CCAMLR № WGEMM-16/55, 19 June 2016, 1-4.

22. Milinevsky, G., Dykyy, I., Lutsenko, D., Savitsky, O., Simon, A., Telipska, M., Lytvynov, V. Pshenichnov, L. 2017a. CEMP cameras and satellite transmitters installation by Ukraine at the Galindez, Petermann, and Yalour Islands penguin colonies as a part of CEMP Fund projects. Document CCAMLR № WG-EMM-17/21, 26 June 2017, 1-2.

23. Milinevsky, G., Dykyy, I., Watters, G., Hinke, J., Santos, M., Korczak-Abshire, M., Southwell, C., Emmer- son, L., Lytvynov, V., Khoetsky, P., Veselsky, M., Utevsky, A., Shmyrov, D., Telipska, M., Parnikoza, I., Lutsenko, D., Savitsky, O., Grytsai, Z., Simon A. 2017b. The CEMP Camera / Transmitter Network for ecosystem study in Antarctica. VIII International Antarctic Conference Dedicated to the 25th anniversary of Ukraine's accession to the Antarctic Treaty. Kyiv, Ukraine, 16-18 May, 2017, 73-76.

24. Montes-Hugo, M, Doney, S.C., Ducklow, H.W., Fraser, W, Martinson, D, Stammerjohn, S.E, Schofield, O. 2009. Recent changes in phytoplankton communities associated with rapid regional climate change along the Western Antarctic Peninsula. Science, 323 (5920), 1470-1473. DOI: 10.1126/science. 1164533

25. Muller-Schwarze, C., Muller-Schwarze, D. 1975. A survey of twenty-four rookeries of pigoscelid penguins in the Antarctic Peninsula region. The biology of penguins. London: Macmillan, 209-320.

26. Nicol, S. 2000. Krill, currents and sea ice: Euphausia superba and its changing environment. Bioscience, 56, 111-120.

27. Olenin, S., Alemany, F., Cardoso, A.C., Gollasch, S., Goulletquer, P., Lehtiniemi, M., McCollin, T., Minchin, D., Miossec, L., Ambrogi, A.O., Ojaveer, H., Jensen, K.R., Stankiewicz, M., Wallentinus, I., Aleksandrov, B. 2010. Marine strategy framework directive. Joint Report. Luxembourg: Office for Official Publications of the European Communities. DOI: 10.2788/87092

28. Otley, H.M., Clausen, A.P., Christie, D.J., Pütz, K. 2005. Aspects of the breeding biology of the Gentoo Penguin Pygoscelis papua at Volunteer Beach, Falkland Islands. Marine Ornithology, 2001/02, 33, 167-171. Available online:: http://www.marineornithology.org/PDF/32_2/32_ 2_167-171.pdf

29. Peklo, A.M. 2001. Materialy po vydovomu sostavu i kolychestvennomu raspredeleniyu ptytc v prolive Dreika i na sopredelnych akvatorijach v marte $1998 \mathrm{~g}$. [Materials on species composition and quantitative distribution of birds in the Drake Passage and on adjacent water area in March 1998]. Vysnyk naukovo-pryrodnychogo muzeju NAN Ukrainy [Proceedings of the national sciences natural history museum of NAS Ukraine], 1, 132-137. 
30. Peklo, A.M. 2007. The Birds of Argentine Islands and Petermann Island. Kryvyy Rih: Mineral Publishers.

31. Peklo, A.M., Dykyy, I.V. 2010. On some rare bird species of the Argentine islands (Antarctica). Zbirnik prac' Zoologičnogo muzeû (Kyiv), 41, 145-153. Available online: http:// museumkiev.org/zoo/catalog/zz_41/41_2010_Peklo_ Dykyy.pdf

32. Pilipenko, D.V. 2013. The colonial species bird nesting near Ukrainian Antarctic station Academic Vernadsky (the season 2010-2011 years). Ukrainian Antarctic Journal, 12, 206-216. Available online: http://uaj.uac.gov.ua/sites/ default/files/documents/uaj12_206.pdf

33. Poncet, S., Poncet, J. 1987. Censuses of penguin populations of the Antarctic Peninsula, 1983-87. British Antarc- tic Survey. Bulletin, 77, 109-129. Available online: http://www.an tarctica.ac.uk/documents/bas_bulletins/bulle tin77_07.pdf

34. Saba, G.K., Fraser, W.R., Saba, V.S., Iannuzzi, R.A., Coleman, K.E., Doney, S.C., Ducklow, H.W., Martinson, D.G., Miles, T.N., Patterson-Fraser, D.L., Stammerjohn, S.E., Steinberg, D.K., Schofield, O.M. 2014. Winter and spring controls on the summer food web of the coastal West Antarctic Peninsula. Nature Communications, 5, 4318, 1-8. DOI: $10.1038 /$ ncomms5318.

35. Schofield, O., Ducklow, H.W., Martinson, D.G., Meredith, M.P., Moline, M.A., Fraser, W.R. 2010. How do polar marine ecosystems respond to rapid climate change? Science, 328, 1520-1523. DOI: 10.1126/science.1185779.

36. Slezak, M. 2017. Penguin disaster as only two chicks survive from colony of 40,000. The Guardian. Available on- line: https://www.theguardian.com/environment/2017/ oct/12/penguin-catastrophe-leads-to-demands-for-pro tec-tion-in-east-antarctica

37. Smagol, V., Molchanoff, S. 2016. The Topical Segregation of Penguins of Genus Pygoscelis and Antarctic shags (Phalacrocorax bransfieldensis). Ukrainian Antarctic Journal, 15, 106-113. Available online: http://uaj.uac.gov. ua/ sites/ default/files/documents/uaj15-2016\%20 $\% 2812 \% 29$.pdf

38. Southwell, C.J., McKinlay, J., Low, M, Wilson, D., Newbery, K., Lieser, J.L., Emmerson, L.M. 2013. New methods and technologies for regional-scale abundance estimation of land-breeding marine animals: application to Adélie penguin populations in East Antarctica. Polar Biology, 36, 843-856.

39. Southwell, C.J., Emmerson, L.M., Newbery, K. 2011. Using automated cameras as a cost-effective means of extending land-based predator monitoring. Document CCAMLR № $W G$-EMM-11/37, 26 June 2011, 1-2.

40. Trivelpiece, W.Z., Hinke, J.T., Miller, A.K., Reiss, C.S., Trivelpiece, S.G., Watters, G.M. Variability in krill biomass links harvesting and climate warming to penguin population changes in Antarctica. PNAS, 11(108), 7625-7628. DOI: org/10.1073/pnas.1016560108

41. Vaughan, D.G., Marshall, G.J., Connolley, W.M., Parkinson, C., Mulvaney, R., Hodgson, D.A., King, J.C., Pudsey, C.J., Turner J. 2003. Recent rapid regional climate warming on the Antarctic Peninsula. Climate Change, 60, 243-274. DOI: 10.1023/A:1026021217991.

\section{І. В. Дикий ${ }^{1,2}$, Г. П. Міліневський $2,3,4, *$, О. Л. Савицький ${ }^{5}$, Д. Г. Луценко ${ }^{6}$,}

П. Б. Хоєцький ${ }^{2,}$, М. Ф. Весельський ${ }^{8}$, В. М. Смаголь ${ }^{9}$, Є.О. Дикий ${ }^{2}$, А. О. Джулай ${ }^{2}$,

Й. В. Царик ${ }^{1}$, К. М. Назарук ${ }^{1}$, А. Т. Затушевський ${ }^{10}$, А. О. Сімон ${ }^{4}$, М. А. Теліпська ${ }^{1}$

'Львівський національний університет імені Івана Франка, м. Львів

${ }^{2}$ Державна установа Національний антарктичний науковий центр МОН України, м. Київ

${ }^{3}$ Коледж фізики, Міжнародний центр науки майбутнього, Цзилінський університет, м. Чанчунь, Китай

${ }^{4}$ Київський національний університет імені Тараса Шевченка, м. Київ

${ }_{5}^{5}$ Інститут гідробіології, Національна академія наук України, м. Київ

${ }^{6}$ Інститут проблем кріобіології і кріомедицини Національна академія наук України, м. Харків

${ }^{7}$ Національний лісотехнічний університет України, м. Львів

${ }^{8}$ Житомирський обласний краєзнавчий музей, м. Житомир

${ }_{9}^{9}$ Інститут зоології імені І. І. Шмальгаузена Національної академія наук України, м. Київ

${ }^{10}$ Зоологічний музей Львівського національного університету імені Івана Франка, м. Львів

*Corresponding author: genmilinevsky@jlu.edu.cn, genmilinevsky@gmail.com

\section{ОСОБЛИВОСТІ ХРОНОЛОГІЇ Й УСПІШНОСТІ РОЗМНОЖЕННЯ ПIНГВIHIВ PYGOSCELIS PAPUA TA P. ADELIAE (SPHENISCIDAE) В РАЙОНI АРХІПЕЛАГУ ВІЛЬГЕЛЬМА (ПІДРАЙОН ССАМLR 48.1)}

РЕФЕРАТ. Мета. Дослідити якісні зміни в оселищах двох найпоширеніших видів пінгвінів на архіпелазі Вільгельма Pygoscelis papua та P. adeliae (Spheniscidae) y підрайоні CCAMLR 48.1 під впливом зміни клімату та промислу криля. Методи. Щоб мінімізувати людський вплив на успішність розмноження й виживання пташенят та уникнути чинник турбування пінгвінів, використано новий спосіб спостереження за розмноженням пінгвінів з використанням фото- 
камер, які встановлені в колоніях пінгвінів. Було встановлено терміни появи в колонії, копуляції, відкладання яєць, вилуплення пташенят та формування ясел. Цей метод було вперше використано в рамках міжнародного проекту СЕМР “Створення мережі камер СЕМР в підрайоні 48.1”. Проект триватиме більш ніж п'ять років. Також проводили візуальні спостереження за птахами. Результати. За останнє десятиліття гніздовий ареал $Р$. рариа змістився на південь майже на 30 км, у результаті пінгвіни утворили шість нових гніздових колоній. Щорічна успішність розмноження P. рариа на острові Пітерман становила від 0,87 до 1,58 пташенят на гніздо протягом дев'яти сезонів спостережень у 2003-2017 pp. У 2017/16 pр. відзначено 1,27 пташенят на гніздо; це низький рівень успішності розмноження порівняно з іншими сезонами. Успішність розмноження P. adeliae була більш стабільною, за шість сезонів спостережень (від 1,11 до 1,42); з найвищим показником у 2003/04 pp. 3'ясовано спектр живлення $P$. рариа. Висновки. На території архіпелагу Вільгельма відмічені зміни в оселищах пінгвінів. Встановлено, що на початку XXI століття ареал гніздування P. рариа значно розширився, ймовірно, через потепління клімату в регіоні. Показано, що Р. рариа є більш екологічно пластичним видом, ніж $P$. adeliae. Відомо, що успішність розмноження хижаків, таких як пінгвіни, може бути використано як індикатор статусу нижчих трофічних рівнів, оскільки антарктичний криль Euphausia superba (Euphausiidae) $€$ основним об'єктом харчування пінгвінів (84 \%) у районі архіпелагу Вільгельма. Ми пропонуємо модель ключових елементів для якісного та кількісного аналізу змін екосистеми Аргентинських островів базованої на крилю. Майбутній розвиток моніторингу гніздових колоній пінгвінів з використанням мережі Camera Network CEMP в рамках ККАМЛР буде значною мірою сприяти оцінці реальної доступності здобичі. Результати дослідження успішності розмноження $P$. papиa та $P$. adeliae можуть бути використані (1) у розробці стратегії управління промислу криля в ККАМЛР для раціонального використання морських природних ресурсів Антарктики; (2) розробці моделі розселення для прогнозування екологічних ризиків через зміни клімату для обох видів пінгвінів.

Ключові слова: Pigoscelis papиa, Pigoscelis adeliae, успішність розмноження, вміст шлунку, криль, мережа камер СЕМР, Антарктичний півострів. 